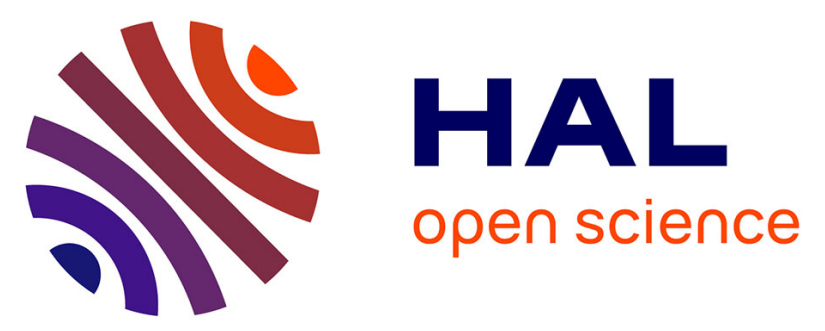

\title{
Carboxylic acid sorption on synthetic clays in marine water: in vitro experiments and implications for organo-clay behaviour under marine conditions
}

Sylvain Drouin, Mohammed Boussafir, Jean-Louis Robert, Patrick Albéric, Aude Durand

\section{To cite this version:}

Sylvain Drouin, Mohammed Boussafir, Jean-Louis Robert, Patrick Albéric, Aude Durand. Carboxylic acid sorption on synthetic clays in marine water: in vitro experiments and implications for organo-clay behaviour under marine conditions. Organic Geochemistry, 2010, 41 (2), pp.192-199. 10.1016/j.orggeochem.2009.10.006 . insu-00415576

\section{HAL Id: insu-00415576 \\ https://hal-insu.archives-ouvertes.fr/insu-00415576}

Submitted on 10 Sep 2009

HAL is a multi-disciplinary open access archive for the deposit and dissemination of scientific research documents, whether they are published or not. The documents may come from teaching and research institutions in France or abroad, or from public or private research centers.
L'archive ouverte pluridisciplinaire HAL, est destinée au dépôt et à la diffusion de documents scientifiques de niveau recherche, publiés ou non, émanant des établissements d'enseignement et de recherche français ou étrangers, des laboratoires publics ou privés. 
Carboxylic acid sorption on synthetic clays in marine water: in vitro experiments and implications for organo-clay behaviour under marine conditions

Sylvain Drouin ${ }^{a}$, Mohammed Boussafir ${ }^{a^{*}}$, Jean-Louis Robert ${ }^{\text {b }}$, Patrick Alberic ${ }^{\text {a }}$, Aude Durand $^{\mathrm{a}}$

a Université d'Orléans, CNRS/INSU, Université François Rabelais - Tours, Institut des Sciences de la Terre d'Orléans - UMR 6113 Campus Géosciences, 1A, rue de la Férollerie , 45071 Orléans cedex 2 France

${ }^{\mathrm{b}}$ IMPMC, UMR 7590, Campus Boucicaut, 140 rue de Lourmel, 75015 Paris, France

* Corresponding author. Tel: 33 (0)2 384947 38; fax: 33 (0)2 38417308.

E-mail address: Mohammed.Boussafir@univ-orleans.fr 


\begin{abstract}
In order to investigate the role of clay minerals in organic matter preservation, the fixation of pure organic compounds on two synthetic low- and high-charge saponites was investigated in laboratory experiments simulating marine water conditions. The clays were exposed to four carboxylic acids: pentadecanoic, docosanoic, $5 \beta$-cholanic acid and ursolic, dissolved in treated natural sea water. Characterization of the resulting organo-clay association indicates that, under marine water column conditions, the organic fixation is only a sorption process, no intercalation being observed. The surface coverage, similar for the two clays (ca. $0.04 \mathrm{mg}$ organic carbon $\mathrm{m}^{2}$ ), demonstrates that the sorption is controlled by the surface properties of clays rather than their cation exchange capacity. The weaker sorption of docosanoic acid underlines the major role of the molecular properties, but the lack of selectivity among the three others does not corroborate the influence of molecular size on the sorption process. The general failure of a chemolysis treatment performed on the organo-clay associations demonstrates the high stability of these complexes. Results suggest that the bonding mechanisms are dominated by ligand exchange and not by hydrophobic effects, cation bridges or cation exchange. The minor extractible organic fraction consists of acid molecules connected to clay surfaces by van der Waals interactions.

The high stability of the bonds formed in this environment, close to those observed from previous studies of marine sediments, could explain in part the organic matter preservation during transfer across marine water columns, especially metabolisable materials.
\end{abstract}

Keywords: organic molecules, carboxylic acids, clays, sorption, organic matter, preservation, marine sedimentation 


\section{INTRODUCTION}

Several mechanisms are postulated to explain organic matter (OM) accumulation in sediments and sedimentary rocks. Besides the classical degradation-recondensation model (Tissot and Welte, 1984) and the now accepted selective molecular preservation (Largeau et al., 1984; Tegelaar et al., 1989; Boussafir et al., 1997) and sulfurization pathways (Sinninghe Damsté and de Leeuw, 1990; Boussafir et al., 1995), the sorption of organic molecules on clay surfaces is hypothesized as one of the main mechanisms controlling organic sedimentation fluxes and preservation (Keil et al., 1994a; Mayer, 1994; Papadimitriou et al., 2002). It is a fact that a large proportion of organic-rich sediments are clayey in type, as demonstrated by many examples of petroleum source rocks (Huc et al., 1992; Crossey at al., 1992). However, the principal argument in favour of effective organic preservation by sorption on clays is the observation at the nanoscopic scale of an intimate relationship between $\mathrm{OM}$ and clays (nanolayer alternations) in petroleum source rocks and recent upwelling sediments (Salmon et al., 2000; Pichevin et al., 2004). Moreover, a strong relation between organic carbon concentration and mineral surface area in recent marine sediments has been well documented (Mayer 1994; Keil et al., 1994a, b; Hedges and Keil, 1995; Bergamishi et al., 1997).

If the existence of organo-clay complexes in sediments and their major role in organic preservation in this environment seems to be accepted, the conditions of the organo-clay interactions are still debated. In these discussions, the fixation of OM by mineral fractions in the water column is rarely considered. It is accepted that physical and chemical interactions are possible and produce the flocculation of organo-mineral complexes (Jackson, 1990). The organo-mineral flocculation decreases the transfer time of metabolisable organic compounds through the water column (Wackeman et al., 1984a, b). In this sense, the possibilities of 
oxidation and/or bacterial recycling during transfer in the water column are reduced (Degens et al., 1976; Demaison and Moore, 1980). Recent works of Curry et al. 2007 on the finegrained sediment show clearly the protective role of the encapsulation of clay to enzymatic attack. Nevertheless, to our knowledge, the nature of organo-mineral interaction under water column conditions by in vitro experiments has rarely been studied. Hedges in 1977 experimented the associations of small molecules such as glucose and valine with clay minerals. He demonstrates that clays preferentially remove some small dissolved organic molecules. In natural seawater, carboxylic acids are one of the most abundant dissolved organic molecules (Thurman, 1985). Meyers and Quinn (1971, 1973) and Sansone and collaborators (1987) have shown that, under saline conditions, sediments and pure clays are able to adsorb linear saturated as well as unsaturated fatty acids (FAs) in high proportion. Some of these authors (Sansone et al., 1987) have used only short-chain organic acids in their experiments. However, such studies on lipids are scarce, possibly because the low solubility of FAs in water makes the experiments challenging.

Many unresolved questions remain on this topic. In which proportion can clays trap organic molecules, particularly lipids that possess a high petroleum potential under marine water conditions? Does a molecular selectivity exist during fixation processes under these conditions? Do clay mineralogy and surface structure affect organo-mineral interactions? Which bonding mechanisms are involved? What is the stability of the complexes formed under marine water conditions? These questions are of interest with respect to the role of clays on organic matter fossilization. The aim of this study was to investigate the extent and mechanisms of OM fixation by clay minerals in the marine environment. The objectives were first to reproduce the trapping of selected lipids, i.e. carboxylic acids, dissolved in natural sea water, on well known synthetic clay minerals under laboratory conditions, and characterize 
the organo-mineral complexes. Secondly, the aim was to test the stability of these assemblages through saponification-like chemolysis.

\section{Materials and methods}

\subsection{Materials}

Natural sea water was collected from the Brittany coast at Combrit Sainte-Marine (Finistère, France). It has a salinity of $33 \mathrm{psu}$ and $\mathrm{pH}$ of 7.8, and was first filtered on $0.22 \mu \mathrm{m}$ hydrophilic membranes and then treated with ultraviolet radiation to eliminate natural OM. Total organic carbon (TOC) concentration was measured after treatment to verify removal of OM.

The use of synthesised clays provides monophasic minerals with well known chemical composition and properties, saponites being selected here as a model. These minerals belonging to the smectite family and, like the montmorillonites, are close to natural clay materials observed in several marine sediments (Windom, 1976). Moreover, their charge can be more easily varied than in montmorillonite, in order to test its impact during organo-clay interactions. Saponites were prepared via hydrothermal synthesis, following a method derived from the procedure of Hamilton and Henderson (1968). Two types of saponite were employed, with structural formulae $\mathrm{Na}_{0.4} \mathrm{Mg}_{3}\left(\mathrm{Si}_{3.6} \mathrm{Al}_{0.4}\right) \mathrm{O}_{10}(\mathrm{OH})_{2} \cdot \mathrm{nH}_{2} \mathrm{O}$ (charge 0.4) and $\mathrm{Na}_{0.8} \mathrm{Mg}_{3}\left(\mathrm{Si}_{3.2} \mathrm{Al}_{0.8}\right) \mathrm{O}_{10}(\mathrm{OH})_{2} \cdot \mathrm{nH}_{2} \mathrm{O}$ (charge 0.8 ). These clays mainly exhibit the two-layer water state $(n=5)$, under water-saturated conditions. They have a measured surface area and cation exchange capacity of $46 \mathrm{~m}^{2} \mathrm{~g}^{-1}$ and $103 \mathrm{meq}$, respectively (low-charge saponite) and 36 
$\mathrm{m}^{2} \mathrm{~g}^{-1}$ and $201.7 \mathrm{meq}$ (high-charge saponite). Before the experiments, no solvent or heating treatment was applied to the clays in order to prevent modification of the surface properties. They were were lyophilized and analyses performed to make sure that no organic pollution occurred during their synthesis.

The solutions used in the experiments were of pentadecanoic acid $\left(\mathrm{C}_{15} \mathrm{H}_{30} \mathrm{O}_{2} ; \mathrm{pKa} 4.78 \pm\right.$ 0.10), docosanoic acid $\left(\mathrm{C}_{22} \mathrm{H}_{44} \mathrm{O}_{2} ; \mathrm{pKa} 4.75 \pm 0.10\right)$, $5 \beta$-cholanic acid $\left(\mathrm{C}_{24} \mathrm{H}_{40} \mathrm{O}_{2} ; \mathrm{pKa} 4.76 \pm\right.$ $0.10)$ and ursolic acid $\left(\mathrm{C}_{30} \mathrm{H}_{48} \mathrm{O}_{3}\right.$, with one alcohol function; $\left.\mathrm{pKa} 4.68 \pm 0.7\right)$ at the same concentrations. The chain lengths are closely related to those of carboxylic acids present in natural sea water (predominance of palmitoleic $\mathrm{C}_{16} \mathrm{H}_{30} \mathrm{O}_{2}$ and linoleic $\mathrm{C}_{18} \mathrm{H}_{32} \mathrm{O}_{2}$ acids and their saturated counterparts, palmitic $\mathrm{C}_{16} \mathrm{H}_{32} \mathrm{O}_{2}$ and stearic $\mathrm{C}_{18} \mathrm{H}_{36} \mathrm{O}_{2}$ ) acids (Schwarzenbach et al., 1993). The choice of uncommon marine acids was to ensure that the trapped acids were from organic solution, rather than from acids possibly remaining in the natural seawater after the purification treatment. Different types of acids (linear, and cyclic with and without alcohol function) were chosen in order to investigate the fixation mechanisms and possible competition between organic species.

An aliquot of the organic solution was added to seawater, to give a solution with $2.5 \mathrm{mg} \mathrm{C}$ $1^{-1}$, similar to dissolved organic carbon concentration in natural seawater (Schwarzenbach et al., 1993). Under the $\mathrm{pH}$ conditions of the experiments, the carboxylic functions are anions.

\subsection{Experimental}

The saponites $(200 \mathrm{mg})$ were dispersed under agitation $(2 \mathrm{~h})$ in the treated natural seawater prior to interaction with the carboxylic acid solution. This procedure was carried out to make sure the clays reached the maximum swelling state before organo-mineral interaction (Bader et al., 1960). A solution containing $3.3 \mathrm{mg} \mathrm{C} \mathrm{C}_{15} \mathrm{H}_{30} \mathrm{O}_{2}$ (pentadecanoic acid), $3.1 \mathrm{mg}$ 
$\mathrm{C}_{22} \mathrm{H}_{44} \mathrm{O}_{2}$ (docosanoic acid), $2.9 \mathrm{mg} \mathrm{C}_{24} \mathrm{H}_{40} \mathrm{O}_{2}$ (5ß-cholanic acid) and $3.1 \mathrm{mg} \mathrm{C}_{30} \mathrm{H}_{48} \mathrm{O}_{3}$ (ursolic acid) in $10 \mathrm{ml} \mathrm{MeOH}$ was prepared. An aliquot $(1 \mathrm{ml})$ of this solution was added to each clay suspension. The volumes were made up to $500 \mathrm{ml}$ with treated natural seawater.

The mixtures were soaked $(24 \mathrm{~h})$ at room temperature to favour maximum fixation by the saponite surfaces (Meyers, 1971; Arnarson and Keil, 2000) and the saponites separated from solution by centrifugation. Before characterization of organo-mineral complexes formed, the saponites were washed with distilled water, lyophilized, homogenized by crushing and then frozen. The organo-clay interaction experiments with the low- and high-charge saponites were carried out in duplicate to confirm the reproducibility of the experimental protocol.

\subsection{Analytical techniques}

TOC analysis was performed on the saponites after interaction with the solution. About 35 mg of lyophilized saponite were analyzed with an elemental carbon analyzer CNS 2000 LECO $^{\circledR}$. Due to the use of synthetic clays (i.e. free of carbonate) the measured C content represents TOC content.

Two types of molecular analysis were carried out. Pyrolysis gas chromatography-mass spectrometry (py-GC/MS) was performed first on the starting solution ( $\mathrm{t}_{0}$ solution), and repeated (at least $3 \mathrm{x}$ ), to allow measurement of the response coefficient of the different acids and to test reproducibility. This was required for quantification of relative abundance. The same analysis was then performed on the clays to characterize the nature and amount of the adsorbed acids. A ThermoFinnigan TRACE-Polaris gas chromatograph-ion trap mass spectrometer coupled to a Fisher GSG Curie Point Pyrolyser was used. Samples were deposited in tube-shaped pyrolysis wires with a Curie temperature of $670^{\circ} \mathrm{C}$. The interface temperature of the pyrolysis unit was set at $240^{\circ} \mathrm{C}$ and the pyrolysis time was $15 \mathrm{~s}$. The gas 
chromatograph was fitted with a Rtx ${ }^{\circledR}-5$ MS column (30 m x $0.25 \mathrm{~mm}$ i.d. $0.25 \mu \mathrm{m}$ film) including $5 \mathrm{~m}$ of guard column. The injector was set at $300^{\circ} \mathrm{C}$ and $\mathrm{He}$ was the carrier gas. The temperature programme was: $40^{\circ} \mathrm{C}(1 \mathrm{~min})$, to $300^{\circ} \mathrm{C}$ (hold $30 \mathrm{~min}$ ) at $5^{\circ} \mathrm{C} \mathrm{min}^{-1}$. The mass spectrometer conditions were: electron ionisation (EI), scan range $m / z 50-650$ in $0.58 \mathrm{~s}$, electron energy $70 \mathrm{eV}$. Acids were methylated for pyrolysis, via tetramethylammonium hydroxide (TMAH) thermochemolysis. Compounds were identified by comparison with standards and library mass spectra.

Prior to py-GC/MS analysis of the $t_{0}$ solution, carboxylic acids were extracted from $1 \mathrm{ml}$ of solution using ether. The solvent was partially evaporated and the volume was taken to $1 \mathrm{ml}$ with $\mathrm{MeOH} ; 1 \mu \mathrm{l}$ was sampled and deposited on cleaned silica wool for pyrolysis. The area of each peak in the chromatogram was integrated and correction factors determined by normalization to the response of $5 \beta$-cholanic acid. This was repeated before and after each clay py-GC/MS analysis to check the reproducibility of pyrolysis and confirm the stability of the apparatus over a whole day. The correction factors determined from the $\mathrm{t}_{0}$ solution were applied to peak areas measured on chromatograms of saponites. Py-GC/MS of clays was performed on $3.9 \mathrm{mg}$ and $4.3 \mathrm{mg}$ of low- and high-charge saponites, respectively.

X-ray diffraction (XRD) under controlled water vapour pressure was performed on lowcharge saponite. The X-ray patterns were registered with an ARL X'TRA diffractometer (Thermo Electron ${ }^{\circledR}$ Corporation) using filtered $\mathrm{Cu}-\mathrm{K} \alpha$ radiation, and coupled to a Anton Paar Temperature Humidity Chamber. Orientated clay samples were placed inside a chamber at $30^{\circ} \mathrm{C}$ under $90 \%$ humidity, to compare the basal spacings $d_{001}$ before and after experiments. X-ray Photoelectron Spectroscopy (XPS) were performed with an AEI ES 200B ${ }^{\circledR}$ spectrometer using a magnesium anticathode, to detect possible evolution of saponite composition after the interactions. In this technique the proportion of emitted photoelectrons, that may escape the solid without energy loss decreases exponentially with depth and may be 
considered negligible beyond three "mean free paths", i.e. about $7 \mathrm{~nm}$ for silicates (Kuhr and Fitting, 1999). In order to compare spectral responses obtained on clays after experiments, quantitative results are expressed as atomic concentration ratios normalised to silicon, which remains constant. Sensitivity factors for quantitative analysis were previously determined from glasses of known composition. Uncertainties on atomic ratios can be estimated to $\pm 10 \%$ with this method. Special attention was provided to elemental carbon and to its binding energy $\left(\mathrm{C}_{1 \mathrm{~s}}\right.$ photoelectrons) of $285 \mathrm{eV}$.

In order to test the stability of the organo-mineral complexes obtained under basic conditions, the clays were treated with $10 \% \mathrm{NaOH}$ in $\mathrm{MeOH}$ and ether for $2 \mathrm{~h}$ at $30^{\circ} \mathrm{C} ; 50.3$ mg of 0.4-saponite and $48.4 \mathrm{mg}$ of 0.8 -saponite were introduced in two glass bottles in contact with the solution to attempt to chemolytically release the carboxylic acids associated with the clays. Once the chemical treatment process was completed, clay minerals were separated from the solution by centrifugation and rinsed with distilled water.

\section{Results}

\subsection{Characterization of organo-mineral complexes}

The results of LECO analysis performed on low- and high-charge saponites before and after the interaction experiments are shown in Table 1. These confirm that no organic carbon is associated with the saponites after the synthesis processes. Significant organic carbon concentrations are measured for the two saponites (about $0.20 \pm 0.02 \mathrm{wt} \% \mathrm{C}$ associated with 0.4-saponite and $0.15 \pm 0.01 \mathrm{wt} \% \mathrm{C}$ fixed on 0.8 -saponite) after contact with the acid solution. These values represent $32.0 \pm 3.0 \%$ and $23.8 \pm 2.4 \%$ respectively of initial TOC in the solution. The low-charge saponite is apparently able to absorb more acid molecules than the 
high-charge one under seawater conditions. However, the surface coverages are similar, 0.042 $\mathrm{mg}$ OC $\mathrm{m}^{-2}$ for the low-charge and $0.041 \mathrm{mg} \mathrm{OC} \mathrm{m}^{-2}$ for the high-charge saponite. The results confirm the reproducibility of the experimental protocol, with the OC concentrations obtained by duplication being close to those measured during the first experiment.

The molecular responses from py-GC/MS performed on $\mathrm{t}_{0}$ solution and on the two clays before organo-clay interaction are presented in Fig. 1. The reference compound chosen (correction factor 1 ) was $5 \beta$-cholanic acid because it shows the highest response both in both pyrolysis and GC/MS. The correction factors for the other acids, deduced from the analysis of the $\mathrm{t}_{0}$ solution, are $1.85,1.43$ and 0.53 for $\mathrm{C}_{15} \mathrm{H}_{30} \mathrm{O}_{2}, \mathrm{C}_{22} \mathrm{H}_{44} \mathrm{O}_{2}$ and $\mathrm{C}_{30} \mathrm{H}_{48} \mathrm{O}_{3}$, respectively. Molecular analysis confirms the presence of carboxylic acids associated with the synthetic clays after organo-mineral interaction. Examination of peak areas shows that the low-charge saponite traps 1.5 more carboxylic acid molecules per unit mass than high-charge one. The results also indicate that the 0.4 -saponite principally traps the mid-length linear $\mathrm{C}_{15} \mathrm{FA}$, whereas the 0.8 -saponite adsorbs the cyclic $\mathrm{C}_{24}$ acid in highest proportion (Table 2).

To compare the trapping yield for each acid on the low- and high-charge saponites, pyGC/MS results are presented as ratios of individual to total normalized peak areas (Table 2). Despite greater fixation on the low-charge saponite, the proportion of the different acids is similar for the two clays: ca. $30 \%$ of pentadecanoic, $5 \beta$-cholanic and ursolic, and only ca. $10 \%$ docosanoic.

XPS analysis performed on the saponites before and after organo-mineral interactions are presented in Fig. 2. A study of the $\mathrm{Mg} / \mathrm{Si}, \mathrm{Na} / \mathrm{Si}$ and $\mathrm{Al} / \mathrm{Si}$ ratios calculated from XPS and AES responses before the experiments, close to the theoretical ratios of "on-composition" 0.4 and 0.8 -saponites, confirms the reliability of the experimental procedure (Table 3). Minor discrepancies between theoretical and actual $\mathrm{O} / \mathrm{Si}$ values for saponites before interaction can 
be assigned to small variations in hydration state (Rinnert et al., 2005). Comparison of the $\mathrm{Mg} / \mathrm{Si}, \mathrm{Na} / \mathrm{Si}$ and $\mathrm{Al} / \mathrm{Si}$ ratios for the saponites before and after interaction shows a lack of mineralogical transformation during the experiments. These spectrometric analyses performed after the experiments confirm the presence of carbon associated with the clays (Fig. 2). The results corroborate LECO conclusions on organic molecule fixation by clays. The $\mathrm{C} / \mathrm{Si}$ values of 1.39 for low-charge saponite vs. 0.73 for high-charge saponite, confirm that more carboxylic acid molecules are associated with the 0.4 -saponite. Fluctuation in the $\mathrm{O} / \mathrm{Si}$ ratio after interaction is also due to the presence of OM. X-ray diffraction patterns for the 0.4saponite are presented in Fig. 3. For the raw low-charge saponite, the basal spacing $\mathrm{d}_{001}$ is $15.48 \AA$ Á, indicating a "three-layer" hydrate state. The organo - clay interaction induces a minor shift in the basal spacing, $\mathrm{d}_{001} 14.96 \AA$.

\subsection{Stability of organo-mineral complexes}

Py-GC/MS results for extracts from the chemolysis solutions are presented in Fig. 4. Only a very minor part of acids trapped by the saponites is liberated after the chemical treatment of organo-clay complexes. Only $5 \beta$-cholanic acid and ursolic acid are apparent after treatment of the 0.4-saponite. From Table 2, we can compare $\mathrm{C}_{24} / \mathrm{C}_{30}$ ratios before and after treatment. The ratio, ca. 0.6 for the chemolysis solution vs. 0.8 for the organo - 0.4 -saponite complex before chemical treatment, suggests that the ursolic acid is more strongly bonded to the low-charge saponite than $5 \beta$-cholanic acid.

All the acids were present in the lipid extracts obtained after treatment of the organo - 0.8saponite complexes. Comparison of $\mathrm{C}_{15} / \mathrm{C}_{22}$ ratio values ( 2.2 before treatment of 0.8 -saponite and 1.3 in the chemolysis solution) shows that chemolysis desorbs more docosanoic acid than pentadecanoic acid. Similarly, ursolic acid molecules are more tightly adsorbed on the high- 
charge saponite than $5 \beta$-cholanic acid $\left(\mathrm{C}_{24} / \mathrm{C}_{30} 1.2\right.$ in the chemolysis solution vs. 2.3 in organo - 0.8-saponite complex before chemolysis), as observed with the 0.4-saponite.

Accordingly, bonding of the carboxylic acids with the low-charge saponite is more stable than with the high-charge one.

\section{Discussion}

The results from the in vitro experiments show the capacity of synthetic low- and highcharge clay minerals to adsorb pure organic molecules from seawater. This observation corroborates conclusions from previous studies (Arnarson and Keil, 2000; Satterberg et al., 2004) on the contribution of organo-clay interactions to the OM cycle in the natural marine environment.

If organo-clay association leads to preservation of OM from degradation, as suggested by studies of natural OM in sediments (Keil et al., 1994a,b; Mayer, 1994; Papadimitriou et al., 2002), the demonstration that fixation processes take place as early as in the marine water column is fundamental.

The surface coverages, $0.042 \mathrm{mg} \mathrm{OC} \mathrm{m}^{-2}$ for the low-charge saponite and $0.041 \mathrm{mg} \mathrm{OC} \mathrm{m}^{-}$

${ }^{2}$ for the high-charge one, are very similar. They demonstrate that the fixation properties of the two clays are not controlled by the layer charge, but by the specific surface.

Moreover, the data are intermediate between surface coverage values typically found in aluminosilicate sediments from continental margins (0.86 OC $\mathrm{m}^{-2}$; Mayer et al., 1988; Mayer, 1994) and those obtained by Arnarson and Keil (2000) after their organic sorption experiments $\left(0.0015 \mathrm{OC} \mathrm{m}^{-2}\right)$. The important contrast between our results and the natural surface coverage values given by previous authors probably rests on the composition of the OM investigated, which is more diversified in natural environments. Furthermore our 
experiments, performed on clay material in suspension to reproduce marine column conditions, excludes OM trapping in mesopores, as observed by Mayer et al. (1988) and Mayer (1994). One of the major differences between the present work and the previous study lies in the fact that these authors thermally treated their Na-montmorillonite overnight at $400^{\circ} \mathrm{C}$ to eliminate $\mathrm{OM}$. This thermal treatment is likely to severely modify the surface properties of the clay (see Heller-Kallai, 2006 for a compilation), whereas our starting compounds are unmodified raw clays, free of OM.

The differences of OM concentration trapped by the two saponites, deduced from TOC analysis, depends on the surface area, $46 \mathrm{~m}^{2} \mathrm{~g}^{-1}$ for the 0.4 -saponite and only $36 \mathrm{~m}^{2} \mathrm{~g}^{-1}$ for the 0.8 one. Previous experiments, testing OM interactions with different clay minerals, kaolinite and montmorillonite (Xu-Chen Wang and Lee, 1993) and kaolinite, chlorite and montmorillonite (Satterberg et al., 2003), have shown that the proportion of organic molecules adsorbed is a function of the cation exchange capacity (CEC). CEC characterises the aptitude for a clay mineral to exchange compensating cations. In the two saponites in this study, the CEC is directly related to the layer charge. XPS analysis performed on these shows a very constant $\mathrm{Na} / \mathrm{Si}$ ratio after organo-clay interaction, with regard to initial values. They indicate that no $\mathrm{Na}$ was removed from the interlayer space during the interaction process. In this study, the contrasting behaviour of the two saponites contradicts previous conclusions about the role of the CEC, since the low- and high-charge saponites, with very different CEC, exhibit the same fixation capacity by surface unit.

The X-ray pattern of saponite shows no important variation in the basal spacing $\mathrm{d}_{001}$ after interaction. The minor shift observed allows us to reject any intercalation of organic molecules between clay layers. The shift can be sought in interlayer rearrangements of water molecules and/or interlayer cations. This aspect is beyond the scope of the present work but $\mathrm{X}$-ray analysis leads us to conclude that the carboxylic acid fixation is only a sorption process 
on clay surfaces, in both the simulated seawater conditions and probably in natural marine water columns. Consequently, the preservation of $\mathrm{OM}$ by organo-clay interactions in the seawater column, by modification of the availability to enzyme attack (Sugai and Henrichs, 1992), is not due to its intercalation in the clay interlayer space.

Py-GC/MS performed on the two clays shows first that three carboxylic acids (pentadecanoic, $5 \beta$-cholanic and ursolic) are adsorbed in roughly the same proportion on the saponites. These three represent $90 \%$ of the total carboxylic acids adsorbed by the low- and high-charge clays. The lack of selectivity among the three raises several questions.

First, it seems that the terminal alcohol group of ursolic acid does not lead to greater sorption of this compound. This suggests that the alcohol function does not play a major role in sorption in our experiments.

Second, previous studies of organo-iron oxide interaction (Gu et al., 1994, 1995) and organo-clay interaction under marine sedimentary conditions (Arnarson and Keil, 2000), comparing sorption potential of two OM fractions with different nominal molecular weights (MWs), conclude that higher MW fractions are more adsorbed by the mineral surface than the lower MW fractions. According to this, the ursolic acid molecules should be more trapped by saponites than $5 \beta$-cholanic and pentadecanoic acids. The results of the present study do not confirm the molecular size, i.e. the MW, effect of pure carboxylic acids on their sorption on saponites. By contrast, the weaker adsorption of docosanoic acid indicates that the properties of the molecules are a major factor. Probably an increase in chain length reduces the carboxylic acid - clay bond strength.

The general failure of the chemolysis treatment performed on the organo-clay complexes proves that the bonding between organic molecules and clay surfaces is strong and stable. In sediments, more than $90 \%$ of the total OM cannot be separated from the mineral matrix with 
this procedure (Hedges and Keil, 1995). This relationship suggests that OM sorption on mineral surfaces has an influence on OM preservation (Keil et al., 1994a; Mayer, 1994). Lipids are usually considered to constitute a major part of the $10 \%$ of extractable matter from sediments using organic solvents. The stability of organo-clay complexes underlined by the present study suggests that conclusions about OM preservation could also be applied to lipids under seawater column conditions. Moreover, it shows that the stability of organo-clay complexes depends on the nature of both organic molecules and clays.

However, the partial and differential liberation of carboxylic acids during saponification treatment suggests that several bonding modes are involved in organo-clay interactions. Five mechanisms have been mentioned to explain OM sorption on mineral surfaces under sedimentary conditions (Arnarson and Keil, 2000): cation exchange, cation bridge, ligand exchange, van der Waals bonding and hydrophobic effects. Cation exchange consists of replacement of an inorganic cation by an organic one. This substitution leads to the sorption of organic molecules on the negatively charge surfaces of clay minerals, by coulombic attraction (Xu-Chen Wang and Lee, 1993). Ligand exchange is replacement of the acid hydroxyl functions of the OM by hydroxyl groups of the mineral. Ligand exchange is considered as the dominant mechanism to fix humic substances on iron oxide surfaces in freshwater (Davis, 1982; Gu et al., 1995) and may be significant at the hydroxylated edges of clays (Greenland, 1971). Cation bridges are created when a cation acts as a linkage between negative charges of organic molecules and clay surfaces. Van der Waals interactions are short range and become significant at high ionic strength. This mechanism is dominant for humic acid, aliphatic amines, amino acids and natural OM sorption on clays under marine sediment conditions (Rashid at al., 1972; Xu-Chen Wang and Lee, 1993; Arnarson and Keil, 2000). Hydrophobic effects, like van der Waals bonding, are short range and characteristic of non- 
polar organic molecules. These molecules interacting unfavourably with water tend to be fixed on mineral surfaces (Tipping, 1990).

In the present work, the docosanoic acid molecules, more hydrophobic than pentadecanoic acid, are less adsorbed. This observation suggests that hydrophobic effects do not control organic molecule sorption processes. The very low yield from tentative molecular extraction from the saponites, particularly the low-charge one, also excludes the predominance of weak bonds, i.e. van der Waals interactions, between carboxylic acid and clays. However, the extraction of some organic molecules via chemolysis suggests that van der Waals bonding is involved for a minor amount of carboxylic acids in the sorption process. The constant $\mathrm{Na}^{+}$ content of clays after interaction excludes the hypothesis of cation exchange. Surface sodiums in saponites have a half-charge that is not compensated by the tetrahedral sheet, which could be bonded to the negatively charged deprotonated oxygen of the carboxylic functions. They would then act as cation bridges. The similar surface coverages $\left(0.042 \mathrm{mg} \mathrm{OC} \mathrm{m}^{-2}\right.$ for the $0.4-$ saponite and $0.041 \mathrm{mg} \mathrm{OC} \mathrm{m}^{-2}$ for the 0.8 -saponite), exclude this hypothesis since the density of surface $\mathrm{Na}^{+}$, is twice greater in the 0.8 -saponite than in the 0.4 one, without change in the sorption capacity.

Finally, from the results of the present work, and especially considering the high stability of organo-clay complexes, a ligand exchange mechanism, proposed by several authors (Gu et al., 1994; Gu et al., 1995; Arnarson and Keil, 2000) seems reasonable. Further, if edge sites are primarily involved in the strong binding, then this could explain why the sorptive capacity of both clays is similar.

\section{Conclusions}


This study presents in vitro sorption experiments of pure organic molecules on clean synthetic clays. The results confirm the capacity of clays to adsorb organic molecules in sea water columns. No intercalation in the interlayer space was evidenced. The adsorption process and the stability of organo-clay associations are controlled by the surface properties of clays as well as the nature of organic compounds. The commonly observed association between organic matter and clay minerals in marine sediments starts as early as the sedimentation process in the water column.

The contrasting behaviour of the two saponites contradicts previous conclusions since the low-charge clay traps more organic molecules than the high-charge one in spite of the lower CEC value of the low-charge saponite.

The weakly bonded molecules (van der Waals bonding) are easily removed from the clay surfaces as shown by the efficiency of the chemolysis treatment but only represent a minor fraction of the total organic matter trapped. The major part of the organic molecules is strongly bonded via ligand exchange and cannot be removed.

The chemical linkages between organic molecules and clay surfaces, created under the marine environment, could explain the modification in organic matter availability to benthic fauna and bacteria described by Sugai and Henrichs (1992). The high stability of these bonds could be the key point for organic matter preservation during transfer across sea water columns and later in sediments. In this sense the sorption emphasizes the major role of clays on the preservation of some metabolisable organic molecules in marine environments.

\section{Acknowledgements}

We thank P. Baillif, F. Muller and M. Hatton for their help and the two reviewers for their comments and recommendations improving this manuscript. 


\section{References}

Arnarson, T.S., Keil, R.G., 2000. Mechanisms of pore water organic matter adsorption to montmorillonite. Marine Chemistry 71, 309-320.

Bader, R.G., Hood, D.W., Smith, J. B., 1960. Recovery of dissolved organic matter in seawater and organic sorption by particulate material. Geochimica et Cosmochimica Acta $19,236-243$

Bergamashi, B.A., Tsamakis, E., Keil, R.G., Eglinton, T.I., Montluçon, D.B., Hedges, J.I., 1997. The effect of grain size and surface area on organic matter, lignin and carbohydrate concentration, and molecular composition in Peru Margin sediments. Geochimica etCosmochimica Acta 61, 1247-1260.

Boussafir, M., Gelin, F., Lallier-Vergès, E., Derenne, S., Bertrand, P., Largeau, C., 1995. Electron microscopy and pyrolysis of kerogen from the Kimmeridge Clay Formation (UK). Source organisms, preservation processes and origin of microcycles. Geochimica et Cosmochimica Acta 59, 3731-3747.

Boussafir, M., Lallier- Vergès, E., 1997. Accumulation of organic matter in the Kimmeridge Clay Formation (KCF): an update fossilisation model for petroleum source-rocks. Marine and Petroleum Geology 14, 75-83.

Crossey, L.J., Larsen, D., 1992. Authigenic mineralogy of sandstones intercalated with organic-rich mudstones: Integrating diagenesis and burial history of the Mesaverde group, Piceance Basin, NW Colorado. In: Houseknecht, D.W., Pittman, E.D. (Eds.), Origin, Diagenesis, and Petrophysics of Clay Minerals in Sandstones. SEPM Special Publication 47, Tulsa, Oklahoma, pp. 125-144.

Curry, K. J., Bennett, R. H., Mayer, L. M., Curry A., Abril, M., Biesiot, P. M., Hulbert, M. H., 2007. Direct visualisation of clay microfabric signatures driving organic matter 
preservation in fine-grained sediment. Geochimica et Cosmochimica Acta 71, 17091720.

Davis, J.A., 1982. Adsorption of natural dissolved organic matter at the oxide/water interface. Geochimica et Cosmochimica Acta 46, 2381-2393.

Degens, E.T., Mopper, K.M., 1976. Factors controlling the distribution and early diagenesis of organic material in marine sediments. Chemical Oceanography 6, 59-113.

Demaison, G.J., Moore, G.T., 1980. Anoxic environments and oil source bed genesis. Organic Geochemistry $2,1179-1209$.

Greenland, D.J., 1971. Interactions between humic and fulvic acids and clays. Soil Science $111,34-41$.

Gu, B., Schmitt, J., Chen, Z., Liang, L., McCarthy, J.F., 1994. Adsorption and desorption of natural organic matter on iron oxide: mechanisms and models. Environmental Science Technology 28, 38-46.

Gu B., Schmitt J., Chen Z., Liang L., McCarthy J.F., 1995. Adsorption and desorption of different organic matter fractions on iron oxide. Geochimica et Cosmochimica Acta $51,219-229$.

Hamilton, D.L., Henderson, C.M.B., 1968. The preparation of silicate compositions by a gelling method. Mineralogical Magazine 36, 832-838.

Hedges, J.I., 1977. The association of organic molecules with clay minerals in aqueous solutions. Geochimica et Cosmochimica Acta 41, 1119-1123.

Hedges, J.I., Keil, R.G., 1995. Sedimentary organic matter preservation: an assessment and speculative synthesis. Marine Chemistry 49, 81-115.

Heller-Kallai, L., 2006.Thermally modified clay minerals. In: Bergaya, F., Theng B.K.G., Lagaly, G. (Eds.): Handbook of Clay Science, Vol. 1. Elsevier Ltd, pp. 289-308. 
Huc, A.Y., Lallier-Vergès, E., Bertrand, P., Carpentie,r B., Hollander, D.J., 1992. Organic matter response to change of depositional environment in Kimmeridgian shales, Dorset, U.K. In: Whelan, J.K., Farrington, J.W. (Eds.), Organic Matter: Productivity, Accumulation, and Preservation in Recent and Ancient Sediments. Columbia University Press, pp. 469-486.

Jackson, G.A., 1990. A model of the formation of marine algal flocs by physical coagulation processes. Deep Sea Research . Part A. Oceanographic Research Papers 37, 1197 1211.

Keil. R.G., Tsamakis. E., Fuh. C.B., Giddings. J.C., Hedges. J.I., 1994a. Mineralogical and textural controls on the organic composition of coastal marine sediments: Hydrodynamic separation using SPLITT-fractionation. Geochimica et Cosmochimica Acta 58, 879-893.

Keil, R.G., Montlucon, D.B., Prahl, F.G., Hedges, J.I., 1994b. Sorptive preservation of labile organic matter in marine sediments. Nature 370, 549-552.

Kuhr, J.C., Fitting, H.J., 1999. Monte Carlo simulation of electron emission from solids. J. Electron Spectroscopy and Related Phenomena 105, 257-273.

Largeau, C., Casadevall, E., Kadouri, A., Metzger, P., 1984. Formation of botryococcusderived kerogens. Comparative study of immature torbanites and of the extant alga Botryococcus braunii. Organic Geochemistry 6, 327-332.

Mayer, L.M., Macko, S.A., Cammen, L., 1988. Provenance, concentrations and nature of sedimentary organic nitrogen in the Gulf of Maine. Marine Chemistry 25, 291-304.

Mayer, L.M., 1994. Surface area control on organic carbon accumulation in continental shelf sediments. Geochimica et Cosmochimica Acta 58, 1271-1284.

Meyers, P.A., Quinn, J.G., 1971. Fatty acid-clay mineral association in artificial and natural sea water solutions. Geochimica et Cosmochimica Acta 35, 628-632. 
Meyers, P.A., 1972. Association of fatty acids and hydrocarbons with mineral particles in sea water. Ph.D. Thesis, University of Rhode Island.

Meyers, P.A., Quinn, J.G., 1973. Factors affecting the association of fatty acids with mineral particles in sea water. Geochimica et Cosmochimica Acta 37, 1745-1759.

Papadimitrio, S., Kennedy, H., Bentaleb, I., Thomas, D.N., 2002. Dissolved organic carbon in sediments from the eastern North Atlantic. Marine Chemistry 79, 37-47.

Pichevin, L., Bertrand, P., Boussafir, M., Disnar, J.-R., 2004. Organic matter accumulation and preservation controls in a deep sea modern environment: an example from Namibian slope sediments. Organic Geochemistry 35, 543-559.

Rashid, M.A., Buckley, D.E., Robertson, K.R., 1972. Interactions of a marine humic acid with clay minerals and a natural sediment. Geoderma 8, 11-27.

Rinnert, E., Carteret, C., Humbert, B., Fragneto-Cusani, G., Ramsay, J.D.F., Delville, A., Robert, J.-L., Bihannic, I., Pelletier, M., Michot, L.J., 2005. Hydration of a synthetic clay with tetrahedral charges: a multidisciplinary experimental and numerical study. Journal of Physical Chemistry B 109, 23745-23759.

Salmon, V., Derenne, S., Lallier-Vergès, E., Largeau, C., Beaudoin, B., 2000. Protection of organic matter by mineral matrix in a Cenomanian black shale. Organic Geochemistry $31,463-474$.

Sansone, F. J., Andrews C. C., Okamoto, M. Y., 1987. Adsorption of short-chain organic acids onto nearshore marine sediments. Geochimica et Cosmochimica Acta 51, 18891896.

Satterberg, J., Arnarson, T.S. , Lessard, E.J., Keil, R.G., 2003. Sorption of organic matter from four phytoplancton species to montmorillonite, chlorite and kaolinite in seawater. Marine Chemistry $81,11-18$. 
Schwarzenbach, R. P., Gschwend P. M., Imboden D. M., 1993. Environmental Organic Chemistry, Wiley, New York.

Sinninghe Damsté J.S., de Leeuw, J.W., 1990. Analysis, structure and geochemical significance of organically-bound sulphur in the geosphere: state of the art and future research. Organic Geochemistry 16, 1077-1101.

Sugai, S.F., Henrichs, S.M., 1992. Rates of amine acid uptake and mineralization in Resurrection Bay (Alaska) sediments. Marine Ecology 88, 129-141.

Tegelaa, E.W., de Leeuw, J.W., Derenne S., Largeau, C., 1989. A reappraisal of kerogen formation. Geochimica et Cosmochimica Acta 53, 3103-3106.

Thurman, E. M., 1985. Organic Geochemistry of Natural Waters. Martinus Nijhoff/Dr W. Junk Publishers, Dordrecht.

Tipping, E., 1990. Interactions of organic acids with inorganic and organic surfaces. In: Perdue, E.M., Gjessing, E.T. (Eds), Organic Acids in Aquatic Ecosystems. Life Sciences Research Reports. Wiley,Chichester, pp. 209-221.

Tissot, B.P., Welte, D.H., 1984. Petroleum Formation and Occurrence, $2^{\text {nd }}$ edition. SpringerVerlag, New York,

Wakeham, S.G., Farrington, J.W., Gagosian, R.B., 1984a. Variability in lipid flux and composition of particulate organic matter in the Peru upwelling region. Organic Geochemistry 6, 204-215

Wakeham, S.G., Farrington, J.W., Gagosian, R.B., 1984b. Biogeochemistry of particulate organic matter in the oceans: results from sediment trap experiments. Deep Sea Research $31,509-528$

Xu-Chen, W., Lee, C., 1993. Adsorption and desorption of aliphatic amines, amino acids and acetate by clay minerals and marine sediments. Marine Chemistry 44, 1-23 
Figure captions

Fig. 1. Total ion current (TIC) chromatogram from Py-GC/MS analysis with TMAH performed on extracted carboxylic acids from solution at $\mathrm{t}_{0}(\mathrm{a})$ and on low (b) and high (c) charge saponites after organo-mineral interactions $\left(\mathrm{C}_{15}\right.$. pentadecanoic acid; $\mathrm{C}_{22}$, docosanoic acid; chol. ac., 5 $\beta$-cholanic acid; urs. ac., ursolic acid)

Fig. 2. XPS spectral response of low charge saponite before (a) and after (b) interaction with carboxylic acid solution, with focus on $\mathrm{C}$ peak (c: grey curve before and black after interaction); and high charge saponite before (d) and after (e) interaction with carboxylic acid solution, with focus on C peak (f: grey curve, before; and black after interaction)

Fig. 3. XRD pattern of raw 0.4-saponite (grey curve), and 0.4-saponite after organo-clay interaction (black curve)

Fig. 4. TIC chromatogram from Py-GC/MS analysis with TMAH performed on extracted carboxylic acids from solution from chemolysis after attack of the organo-low- (a) and high(b) charge saponite complexes $\left(\mathrm{C}_{15}\right.$, pentadecanoic acid; $\mathrm{C}_{22}$, docosanoic acid; chol. ac., $5 \beta$ cholanic acid; urs. ac., ursolic acid) 
Table 1

Organic carbon (OC) associated with low- and high-charge saponites before and after contact with carboxylic acid solution

\begin{tabular}{|c|c|c|c|}
\hline & Clay mineral & $\mathrm{OC}(\mathrm{wt} \%)$ & $\begin{array}{l}\text { Amount adsorbed OC } \\
\text { from solution (wt } \%)\end{array}$ \\
\hline \multirow{3}{*}{ Before } & 0.4-Saponite & 0.00 & 0.00 \\
\hline & 0.8-Saponite & 0.00 & 0.00 \\
\hline & $0.4-$ Saponite, exp. $1^{\mathrm{a}}$ & 0.20 & 32.0 \\
\hline \multirow{3}{*}{ After } & 0.8 -Saponite, exp. $1^{\mathrm{a}}$ & 0.15 & 23.8 \\
\hline & 0.4 -Saponite, exp. $2^{b}$ & 0.22 & 35.0 \\
\hline & 0.8 -Saponite, exp. $2^{b}$ & 0.16 & 25.4 \\
\hline
\end{tabular}

${ }^{\text {a }}$ First organo-clay experiment.

${ }^{\mathrm{b}}$ Second organo-clay experiment. 
Table 2 -

Integration of carboxylic acid peaks from py-GC/MS chromatograms from clays before chemolysis and on carboxylic acid extracts from chemolysis solution

\begin{tabular}{|c|c|c|c|c|c|c|c|}
\hline & Clay mineral & $\begin{array}{c}\text { Pentadecanoic } \\
\text { acid }\left(\mathrm{C}_{15}\right)\end{array}$ & $\begin{array}{l}\text { Docosanoic } \\
\text { acid }\left(\mathrm{C}_{22}\right)\end{array}$ & $\begin{array}{c}5 \beta \text {-cholanic } \\
\text { acid }\left(\mathrm{C}_{24}\right)\end{array}$ & $\begin{array}{c}\text { Ursolic } \\
\text { acid }\left(\mathrm{C}_{30}\right)\end{array}$ & $\begin{array}{l}\text { Ratios } \\
\mathrm{C}_{15} / \mathrm{C}_{22}\end{array}$ & $\begin{array}{l}\text { Ratios } \\
\mathrm{C}_{24} / \mathrm{C}_{30}\end{array}$ \\
\hline \multirow{2}{*}{$\begin{array}{c}\text { In clay before } \\
\text { chemolysis }\end{array}$} & 0.4-Saponite & 36.76 & 6.48 & 25.87 & 31.89 & 5.7 & 0.8 \\
\hline & 0.8-Saponite & 24.55 & 11.24 & 34.72 & 28.48 & 2.2 & 1.2 \\
\hline \multirow{2}{*}{$\begin{array}{c}\text { In solution after } \\
\text { chemolysis }\end{array}$} & 0.4-Saponite & n.d. ${ }^{b}$ & n.d. ${ }^{b}$ & 36.91 & 63.09 & & 0.59 \\
\hline & 0.8-Saponite & 24.72 & 19.24 & 38.82 & 17.21 & 1.28 & 2.26 \\
\hline
\end{tabular}

${ }^{\mathrm{a}}$ The values represented here are the ratios of each individual peak area versus total peak areas of adsorbed carboxylic acids.

${ }^{\mathrm{b}}$ Not detected. 
Table 3

Atomic concentration ratios obtained from XPS and AES on saponites and normalised to $\mathrm{Si}$ (b.i. before interaction, a.i. after interaction)

\begin{tabular}{cccccc}
\hline Clay mineral & $\mathrm{O} / \mathrm{Si}$ & $\mathrm{Mg} / \mathrm{Si}$ & $\mathrm{Na} / \mathrm{Si}$ & $\mathrm{Al} / \mathrm{Si}$ & $\mathrm{C} / \mathrm{Si}$ \\
\hline $\begin{array}{c}\text { Theoretical 0.4- } \\
\text { saponite }\end{array}$ & 3.33 & 0.83 & 0.11 & 0.11 & 0 \\
\hline $\begin{array}{c}\text { 0.4-Saponite } \\
\text { b.i. }\end{array}$ & 3.91 & 0.70 & 0.09 & 0.14 & 0 \\
\hline $\begin{array}{c}\text { 0.4-Saponite } \\
\text { a.i. }\end{array}$ & 4.23 & 0.66 & 0.07 & 0.14 & 1.39 \\
\hline $\begin{array}{c}\text { Theoretical 0.8- } \\
\text { saponite }\end{array}$ & 3.75 & 0.94 & 0.25 & 0.25 & 0 \\
\hline $\begin{array}{c}\text { 0.8-Saponite } \\
\text { b.i. }\end{array}$ & 4.41 & 0.77 & 0.23 & 0.26 & 0 \\
\hline $\begin{array}{c}\text { 0.8-Saponite } \\
\text { a.i. }\end{array}$ & 3.98 & 0.71 & 0.23 & 0.26 & 0.73 \\
\hline
\end{tabular}



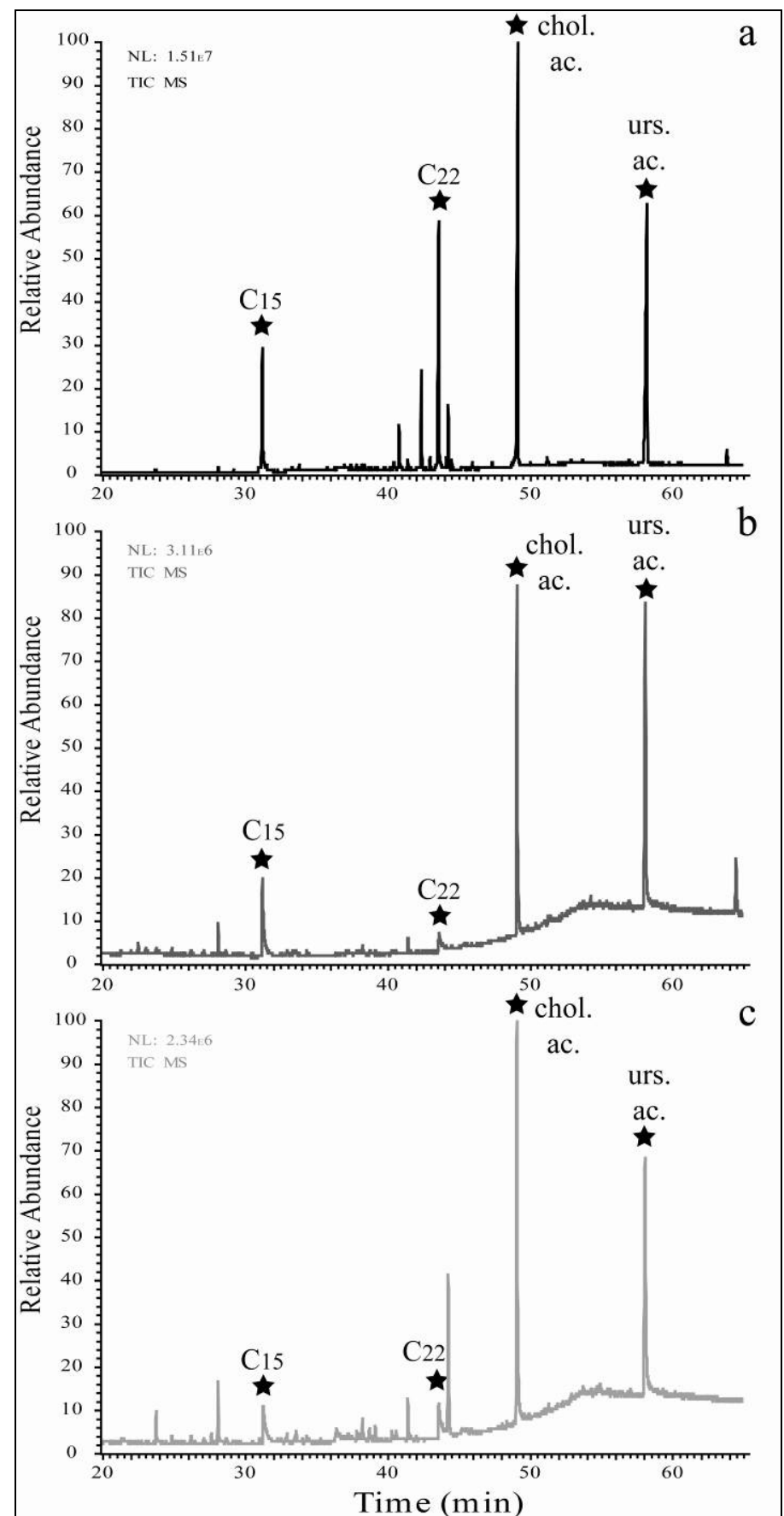

Figure 1 

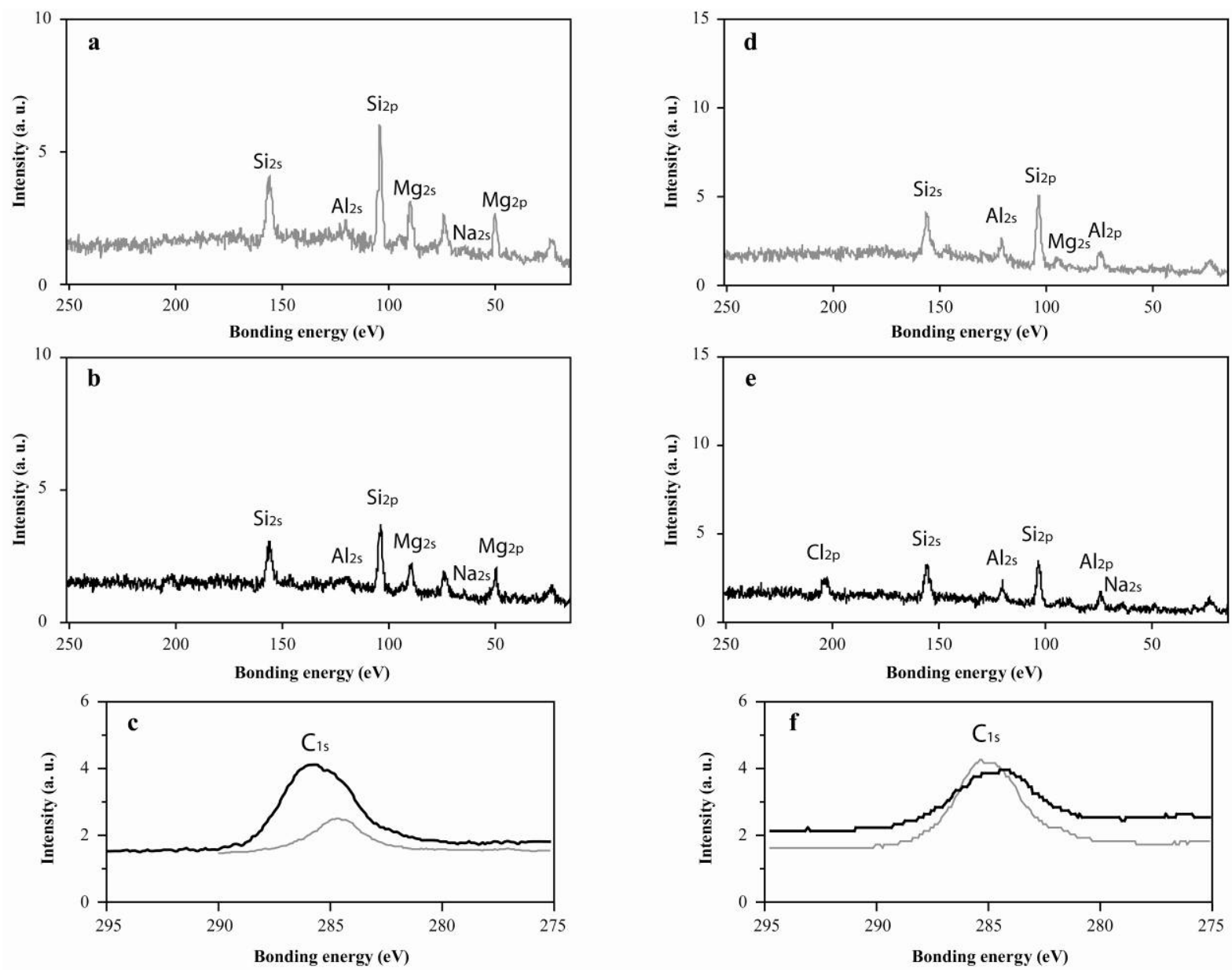

Figure 2 


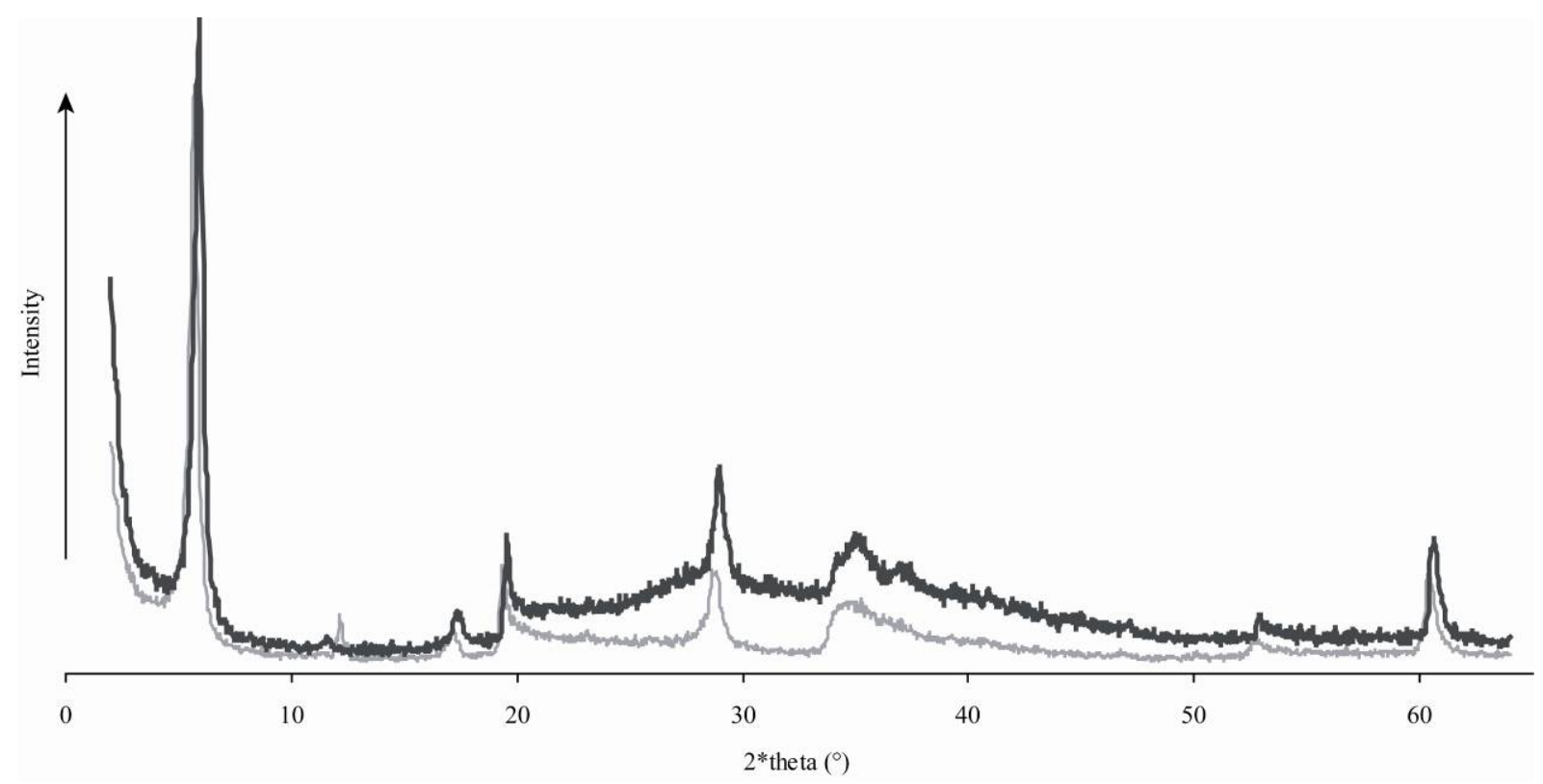

Figure 3 


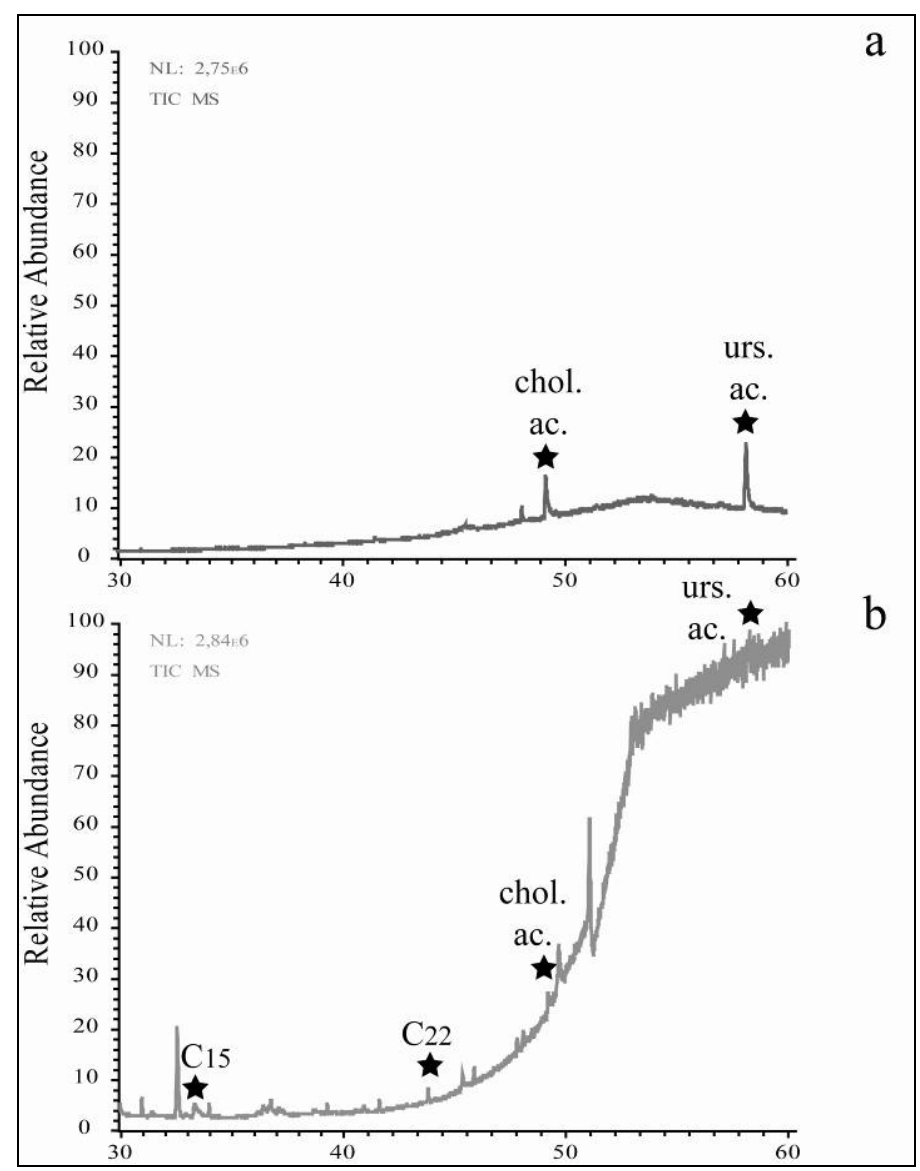

Figure 4 